\title{
The Value of Presuppositions in the Animated Film Nussa And Rara (A Study of Pragmatics)
}

\author{
Riskiana Widi Astuti ${ }^{1}$, Herman $\mathbf{J}_{\text {Waluyo }}{ }^{2}$, and Muhammad Rohmadi ${ }^{3}$ \\ \{riskianawidiastuti@student.uns.ac.id ${ }^{1}$, hermanjwaluyo@staff.uns.ac.id², \\ mamatr76@staff.uns.ac.id ${ }^{3}$ \} \\ ${ }^{1,2,3}$ Universitas Sebelas Maret, Surakarta, Indonesia
}

\begin{abstract}
Pragmatics is the study of the languages involved as intermediaries in the process of speech communication. This research deals with the study of pragmatics with limits on presuppositions with 6 types of presuppositions that is, (1) existential presuppositions, (2) factual presuppositions, (3) lexical presuppositions, (4) non-active presuppositions, (5) structural presuppositions (6) counterfactual presuppositions. Objects used in this research was the animated film Nussa and Rara. the film was chosen by the researcher because the trending on youtube Indonesia's first animated film, which is expected to serve as the formation of character kids which many found irregularities in the country Indonesia committed by older children.limitations of this research only on the analysis of speech are presuppositions expressed in the film. Research through the study of pragmatics presuppositions, using the methods of survey and content analysis research with the kind of qualitative because the resulting data in the form of descriptions of partial speech on animated Nussa and Rara then be divided into six types of speech is presuppositions which are then analyzed. The results reveal that in a speech on the animated film Nussa and Rara had found only five types of presuppositions.
\end{abstract}

Keywords: Presuppositions,Pragmatics, Film

\section{INTRODUCTION}

Social interaction is a social activity that involves two individuals using language as the medium or intermediaries. Interact means that the individual must disclose and may be accountable to what have been Deus Caritas Est. Language is the sole mediator in the communication process using either oral or in writing, the language itself comes from the human mind or individual so that the opponent can understand and respond to. One study of a language that is pragmatic. Pragmatic analysis of functional Linguistics part of having external elements of language comprehensive [1]. Pragmatics cling to external elements that determine the meaning of the speech is the speaker in communicating. The intent of the previous talks that pragmatic meaning is used in the communication process has the goal of keeping the communication process can be run in accordance with the topic of conversation between speakers with partners said. The context is very important in the study of pragmatics, through all the context information can be read by clearly and directional, however, these conditions are 
also affected by the speakers and partners said how good communication with process control. Pragmatic meaning is a marker which is understood to have the meaning of contrast, introduces the counterclaim a claim serves as the device and save face [2]. The importance of understanding the context will be in the use of speech that unveiled by the speakers so that the communication process. Context also inseparable with culture, context and culture always hand in hand but, basically the conditions in the field revealed there are still many misconceptions in expressing and understanding the context or situation said [3]. The use of the context of the functions explained in the communication, namely mutual understanding which was intended.

The wide variety of objects that are used in the study of pragmatics, one of which is the movies. The film is a means of visual shape aims to entertain the audience. Animated films presented in certain forms such as wayang describes motion illusion [4]. The film has a hassle in the process. The provision in the animated film the language of natural and sustainable should be summarized with artistic and rhythm, these activities are done by artists and craftsmen of his time small studio group [5]. Animated right juxtaposed or associated with the study of pragmatics for in the movie there is a process of communication between the player and the opponent play it relates to pragmatics since it includes the purpose of the speech is delivered. The object that will be used in the study of pragmatics is the animated film on youtube trending Indonesia, a pioneer of the film is Mario Irwansyah and on production by the little giant. Film animation titled Nussa and Rara broadcast every Friday on channel youtube Nussa official. Research on highly diverse films, one of which, namely the research titled "The development of three dimensional animation movie for character education media in elementary school." The research is using animated movies to help the development of the learning learners through the animation model designed by $\mathrm{ABC}$ (animation character building) have an impact on positive conditioning as the first step to the formation of character in students of Elementary School [6]. Such research has proven that animated films can help learners in the development of learning. While researchers, animated Nussa and Rara was chosen because it is appropriate to be seen regardless of age restrictions, as well as in the film there is a speech or found from the study of pragmatics.

Presuppositions have six types; existential presuppositions, factual presuppositions, lexical presuppositions, non-active presuppositions, structural presuppositions, and counterfactual presuppositions. [7].The sixth type of presuppositions that have meaning so that the assumption expressed by speakers are also understood by partners said.Speech is the sixth of its kind presuppositions are analyzed through the speech is contained in object movie Nussa and Rara. This study focused on one of the studies of pragmatic presuppositions. Presuppositions are estimated in the communication that the speaker considers partners said understanding what you have described. Presuppositions as language information encoded as a Foundation at the time of utterance that the talks between speakers with listeners have in common in the knowledge that the situation observed in the said [8]. The opinions in this research that strengthens the presuppositions are alleged or estimate in the process of communication between speakers and opponents said, however, the speakers considered that opponents said would also understand what is meant or at the assumption by the speakers. Based on the aforementioned background problem is formulated as follows: How did the presuppositions in the film Nussa and Rara? The purpose of the problems that have been submitted that is knowing the presuppositions in the animated film Nussa and Rara. 


\section{METHOD}

The purpose of the study is to describe the types of objects that are used with the presupposition animated films Nussa and Rara. Through the research objectives of this research including qualitative research because of the data in the form of sentences. Qualitative research data in the form of words, pictures, figures and not the [9]. The methodology used in the survey method research by looking at the object i.e. speech from the animated film Nussa and Rara, through procedures that use the data analyzed in the form of descriptions. Research on a qualitative strength refers to the condition of the particular person or descriptive [10]. Use of content analysis is also needed in the study so that the disclosure of information refers to one's understanding and deepened understanding which examined [11]. Partial speech is animated using the study of pragmatic presuppositions through techniques refer to non-qualified researcher just being an observer [12].

\section{RESULT AND DISCUSSION}

In the study of pragmatics many forms one of the research through the Journal of Germanic Linguistics with the title implicature in lexical semantics, Word Formation, and grammar. The meaning of the pragmatic meaning of an utterance in a situation that is prototypical [13]. The researchers also assume deep meaning in the said right was certainly included in original or prototypical situation because the purpose of the pragmatic i.e. understand what is spoken by the speakers through the context be it in oral, written, time, place and other, etc., also related to the discourse in order to have alignment in compiled a sentence or compose a speech. The discourse is a unit of language that most of the above sentence or clause with the coherence and cohesion of continuous high, capable of having a real start and end, delivered orally or write a cohesive and coherent discourse [14]. The following discussion and analysis of results' presupposition that has researchers found:

\subsection{Existential presuppositions}

(Data 1)

Context : Rara Complained Because It Was Raining

Rara : come on, come on, come on, faster, faster Anta, hhmm rain. We can not ride.

Nussa : Al Asgtafirullah Adzim why is that with rain?

$\ldots$

Partial speech discourse on (1), is a type of existential presuppositions. Existential presuppositions are the assumption that indicates the existence of the phrase or speech. Partial speech "yaaa raining" expressed by Rara, explaining the presence of the rain suddenly came down. Through context can be understood the intent of the character, that Rara provides information indicating the existence of natural conditions presented by the opponent said Nussa, it makes the communicative value in revealing high because both speakers both partners can understand spoken as well as responding to the context of speech communication. The analysis of the aligned with research under the title u.s. Invitations request-for-service mitigators in academic discourse, concerning conflicts of emailing that was essentially a conflict occurs through the context of the talk [15]. Different to that conducted the context i.e. researchers conducted verbally with evidence of speech while employed by earlier research context is done through writing with media mail.

\subsection{Factual presuppositions}


(Data 2)

Context : When Athan Reverberate Shouldn't Play

...

Nussa : You are welcome, but when it is a call to prayer, we should keep silent, it does not mean likes sculpture.

Rara : Yeah I know.

Nussa : You know, but why do you keep playing??

...

Partial speech discourse (2) is a type of factual presuppositions. Factual presuppositions or facts the disclosure describes a reality. Speech is expressed by figures of Nussa "If you've Athan why keep playing?" these figures explain the fact that figures are done by Rara as opposed to said that in the play must have a time or a given time. It is thus indeed has become a habit, particularly on countries that Indonesia must distinguish between play time with a time of worship, so it makes the communicative value of high spoken because either speakers or partners can be said understanding and responding to the context of speech communication. Unlike the Interdiscursive research performance in digital professions: the case of youtube tutorials, the research focuses on the results only on the context for the purpose of maintaining, altering the deprivation to the reader [15]. For researchers that have been explained earlier that relate to the context would definitely bring up a prototypical performance of a context which means it can not change the situation as explained previously aligned with the researchers.

\subsection{Lexical presuppositions}

(Data 3)

Context : Umma Upset Because Nussa And Rara Wasteful

$\cdots$

Rara : Nussa, what's wrong with Umma? She is angry all the time.

Nussa : How is umma not angry? Yesterday the water in the sink overflowing, did you forget to turn it off?

Partial speech on discourse (3) "umma why? Grumpy keep? "is a lexical presupposition. Lexical meaning through the form attested presuppositions which revealed conventional understood or interpreted another meaning that is not expressed or understood. Meaning in speech (3) in Figure Rara asked Nussa's mother with the context and Rara angry can be analyzed "(a) the day that her mother angry, (b) the last day, yesterday, or even (c) tomorrow's mother not angry" thus lexical presupposition equal to well as causal. The analysis research on the similarly titled never done research Speech acts in maritime professional discourse: a pragmatic risk analysis of team communication bridge directives and commissives in full mission simulation results from research This showed that the discourse can be observed spontaneously in conditions of simulated exercises, in this case, showed that the variation of speech is developing through the context of discourse [17]. This analysis more emphasis on what is disclosed has also been understood yet, basically, each partner said not necessarily understanding expressed by the speakers.

\subsection{Non-active presuppositions}

(Data 4)

Context : Rara Complained Because It Was Raining 


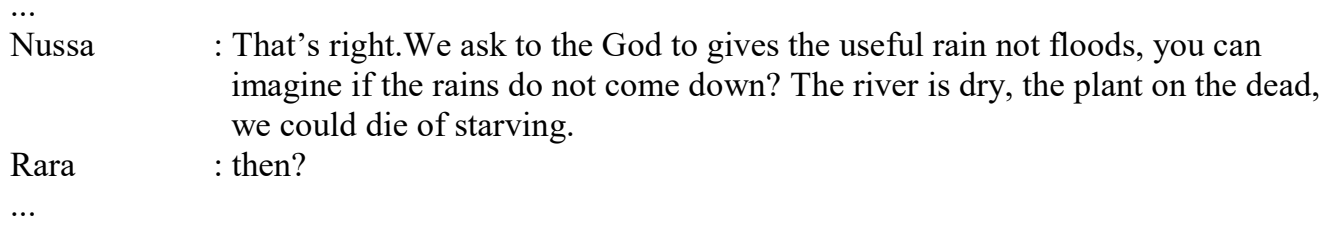

Partial speech discourse next on (4). The non-active presuppositions are the assumption is not true there is no proof. Partial speech (4) "imagine" is a non-active presupposition evidenced on the word imagine visibility or in fact cannot be proved. Figures just imagine if the rain does not come down but in fact conditions in the film have been or still going on raining. The process of communication that occurs between the figures of Nussa as speakers with Rara as the communicative value of expressing said partners expressed high because either speakers or partners can understand spoken as well as responding to the context of the speech such communications. The study entitled Metadiscourse: variation across communicative contexts have the same research results researchers i.e. communicativeness will result in varying contexts [18]. The difference is in the context of the variations do the researcher just focuses on the meantime six types of research that has been done in the context of communicative focuses on academic research by comparing the use of MDMS.

\subsection{Structural presuppositions}

(Data 5)

Context : Rara Got Science of Nussa's Brother about The Solar System

$\cdots$

Nussa : what are you doing guys? This is the name of a miniature of solar system, why is here?

Rara : what is the solar system?

$\cdots$

Partial speech discourse "of the solar system, what the hell?" (5) including structural presuppositions. Structural presuppositions refer to question and sentence structure is known as a problem, however, in the sentence structure has been assumed or presuppositions in his righteousness conventionally. The sentence that expressed question sentence is that figures indeed truth can be proven, namely the solar system as the problem sentence the question requires the right answers concerning the definition of the solar system to the partner said. The study, entitled you're a nuisance! Patch-up jocular abuse in Chinese fiction such as research describing and analyzing context a negative and mixed positive [19]. This is in tune with the analysis conducted researchers but in this case, the researchers included positive research on the category which can be seen through the context of a big sister gives her brother a new science.

\subsection{Counterfactual presuppositions}

Counterfactual presuppositions are the assumption that revealed that contrary to reality. Usually reveal suppositions example "supposing I work" fact "he doesn't work" If analyzed the meaning included in the counterfactual presuppositions because assumptions expressed do not constitute fact happens "he assumes or imagines an activity work.However, in fact, she didn't or such is working ". In fact, the research objects and animated Nussa,Rara counterfactual presuppositions, not found this possibility occurs due to problems of the theme that is always raised in the film is the problem related to the religious, social, culture, environment [20]. 


\section{CONCLUSION}

Pragmatic study that connects the meaning of speech that has been delivered, the study of pragmatic presuppositions have characteristic through variation of the context object that is expressed through animated Nussa and Rara. However, regarding the research, it describes side that is completely original or prototypical found only five types of presuppositions in the film. Counterfactual presuppositions are not found in the implicature of animated films because movies and Rara Nussa only discusses issues related to the religious, social, cultural, environmental, incidentally is not associated with counterfactual presuppositions that discusses the assumptions regarding the disclosure of words assumption or sentences. The analysis of this research has revealed the purpose of the research is to know the presuppositions through the object of animated film of Nussa and Rara by using pragmatics presuppositions.

\section{REFERENCES}

[1] M. Rohmadi. Pragmatik Teori dan Analisis. Surakarta: Yuma Pustaka. 2010.

[2] M. Callies. Information Highligting in Advanced Learner English. Amsterdam: John Benjamis Publishing Company.2009.

[3] J. Sapoetra. "Cross-Cultural Studies and Pragmatic Awareness". Journal EAI. doi.org/10.4108/eai.26-1-2019.2282940.2019

[4] U. Pikkov. Animasophy The Oretical Writings On The Animated Film. USA: Estonian Academy of Arts. 2010.

[5] G. Bendazzi. Twice The Fist Quirino Chistiani and The Animated Feacture Film. New York: CRC Press. 2018

[6] C. Riyana. "The Development of Three Dimensional Animation Film for Character Education Media in Elementary School”. e-journal Upi.2015.

[7] G. Yule. Pragmatik. Yogyakarta: Pustaka Pelajar. 2014

[8] R. P. Kroeger. Analyzing Meaning: An Introduction to Semantic and Pragmatics. Berlin: Language Science Press. 2009.

[9] Basrowi and Suwandi. Memahami Penelitian Kualitatif. Jakarta: Rineka Cipta.2008.

[10] J. A. Maxwell. Qualitative Researah Dessigen an Interative Approach. SAGE Publications. 2012.

[11] Li, Zachao. Understanding-Oriented Multimedia Content Analysis. Singapore: Spinger. 2017.

[12] Muhammad. Metode Penelitian Bahasa. Yogyakarta: Ar-Ruzz. 2011.

[13] T. Becker. "Autohyponymy: Implicature in Lexical Semantics, Word Formation, and Grammar”. Journal of Germanic Linguistics, Vol. 14, No. 02, pp. 105-136, 2002.

[14] T. F. Djajasudarma. Wacana dan Pragmatik. Bandung: Refika Aditama. 2010.

[15] K. Bardovi-Harlig. "Invitations as Request-For-Service Mitigators in Academic Discourse”. Journal of Pragmatics, Vol. 139, pp. 64-78, 2019.

[16] P. John, B. Brooks, and U. Schriever. "Speech Acts in Professional Maritime Discourse: A Pragmatic Risk Analysis of Bridge Team Communication Directives and Commissives in Full-Mission Simulation”. Journal of Pragmatics, Vol. 140, pp. 12-21, 2019.

[17] A. Bhatia. "Interdiscursive Performance in Digital Professions: The Case of YouTube Tutorials". Journal of Pragmatics, Vol. 124, pp. 106-120, 2018.

[18] W. Qin and P. Uccelli. "Metadiscourse: Variation Across Communicative Contexts". Journal of Pragmatics, Vol. 139, pp. 22-39. 2019. 
[19] X. Chen. "You're a nuisance!”: "Patch-up” jocular abuse in Chinese fiction. Journal of Pragmatics, Vol. 139, pp. 52-63, 2019.

[20] K. Saddhono, N. E. Wardani, and C. Ulya. "Sociopragmatic approach on discourse structure of friday prayer's sermon in java and madura island." J. of Lang and Lit, vol. 6 no. 1 pp 26-29, 2015. 